\title{
Fasting ghrelin but not PYY is associated with insulin- resistance independently of body weight in Wistar rats
}

\author{
A grelina, mas não $P Y Y_{(3-36)^{\prime}}$ está associada com a resistência \\ à insulina independente do peso corporal em ratos Wistar
}

Luciana da Conceição Antunes', Manoela Neves da Jornada', Jessica Lorenzzi Elkfury', Kelly Carraro Foletto', Marcello Casaccia Bertoluci'

\begin{abstract}
Objective: The objective of this study was to evaluate the association between insulin-resistance and fasting levels of ghrelin and PYY in Wistar rats. Materials and methods: A total of 25 male Wistar rats, weighing 200-300 g, was included in this study. The animals were maintained in cages with a 12/12h light-dark cycle and fed standard chow and water ad libitum. After 12-h overnight fasting, ghrelin, PYY, insulin and glucose values were determined. Insulin resistance was assessed by means of the HOMA-IR, which was ranked and the median was used as a cut-off value to categorize insulin-resistance. HOMA-IR values equal and above 2.62 were considered insulin-resistant (IR) while values below 2.62 were considered insulin sensitive (IS). Differences between means were determined using the Student t-test. Multiple regression and Pearson's correlation test were used to evaluate the association between variables. Results: HOMA-IR median IQ range values for IS and IR groups were, respectively, $1.56(0.89-2.16)$ vs. [4.06 (3.50 - 4.61); $p<0.001]$. The IR group presented increased levels of fasting ghrelin, PYY and insulin respectively: [50.35 (25.99 - 74.71) pg/mL vs. $12.33(8.77-15.89) \mathrm{pg} / \mathrm{mL} ; p=0.001] ;[54.38$ (37.50 - 71.26) pg/mL vs. 33.17 (22.34 - 43.99) pg/mL; $p=0.016]$; [18.04 (14.48-21.60) uU/mL vs. $7.09(4.83-9.35) \mathrm{uU} / \mathrm{mL} ; p=$ 0.001]. Ghrelin, but not PYY, correlated linearly and positively with HOMA-IR: ghrelin vs. HOMA-IR $(r=0.52 ; p=0.008)$, and PYY vs. HOMA-IR $(r=0.22 ; p=0.200)$. This correlation was independent of body weight. Conclusion: Fasting ghrelin and PYY serum levels are increased in lean, relatively insulin resistant Wistar rats, and this increase is independent of weight. Arq Bras Endocrinol Metab. 2014;58(4):377-81
\end{abstract}

\section{Keywords}

Ghrelin; PYY; insulin resistance; HOMA-IR

\section{RESUMO}

Objetivo: 0 objetivo deste estudo foi avaliar a associação entre a resistência à insulina e os níveis de grelina e PYY em jejum em ratos Wistar. Materiais e métodos: Um total de 25 ratos Wistar machos, pesando 200-300 g, foi usado neste estudo. Os animais foram mantidos em gaiolas com um ciclo de luz escuro de $12 / 12 \mathrm{~h}$ e alimentados com ração padrão e água ad libitum. Depois de um jejum de $12 \mathrm{~h}$, os valores de grelina, PYY, insulina e glicose foram determinados. A resistência à insulina foi avaliada pelo HOMA-IR que foi ordenado e a mediana utilizada como valor de corte para categorizar a resistência à insulina. Os valores de HOMA-IR iguais ou acima de 2,62 foram considerados resistentes à insulina (RI), enquanto valores abaixo de 2,62 foram considerados sensíveis (SI). As diferenças entre as médias foram determinadas usando-se o teste $t$ de Student. A análise de regressões múltiplas e o teste de correlação de Pearson foram usados para se avaliar a associação entre as variáveis. Resultados: A mediana e a variação IO do HOMA-IR para os grupos RI e SI foram, respectivamente, $1,56(0,89-2,16)$ contra $[4,06(3,50-4,61) ; p<$ $0,001]$. O grupo RI apresentou níveis aumentados de grelina, PYY e insulina em jejum, respectivamente, [50,35 $(25,99-74,71) \mathrm{pg} / \mathrm{mL}$ contra $12,33(8,77-15,89) \mathrm{pg} / \mathrm{mL} ; p=0,001] ;[54,38(37,50$ - 71,26) pg/mL contra 33,17 $(22,34-43,99) \mathrm{pg} / \mathrm{mL} ; p=0,016] ;[18,04(14,48-21,60) \mathrm{uU} / \mathrm{mL}$ contra $7,09(4,83-9,35) \mathrm{uU} / \mathrm{mL} ; p=0.001]$. A grelina, mas não PYY, se correlacionou de forma linear e positiva com o HOMA-IR: a grelina contra HOMA-IR $(r=0,52 ; p=0,008)$, e PYY contra HOMA-IR $(r=0,22 ; p=0,200)$. Essa correlação foi independente do peso corporal. Conclusão: Os níveis séricos de jejum de grelina e PYY estão aumentados em ratos Wistar magros relativamente resistentes à insulina, e esse aumento é independente do peso. Arq Bras Endocrinol Metab. 2014;58(4):377-81
'Faculdade de Medicina, Universidade Federal do Rio Grande do Sul (UFRGS), Porto Alegre, RS, Brazil
Correspondence to: Marcello Casaccia Bertoluci Serviço de Medicina Interna, Hospital de Clínicas de Porto Alegre Universidade Federal do Rio Grande do Sul

Rua Ramiro Barcelos, 2350 90035-903 - Porto Alegre, RS, Brazi mbertoluci@uol.com.br

Received on Ago/12/2013 Accepted on Jan/24/2014

DOI: 10.1590/0004-2730000002927 


\section{INTRODUCTION}

I nsulin resistance is a life-long condition associated with increased abdominal adiposity, overfeeding, type 2 diabetes, and cardiovascular disease. Gastrointestinal peptides have been recently associated with control of hunger and satiety, but the link between these peptides and insulin-resistance has not been completely determined.

Ghrelin is the only known circulating orexigenic peptide, primarily produced in stomach, but also in smaller concentrations in the small intestine, liver, pancreas, kidney, lung, pituitary, hypothalamus, placenta and testes (1). Under physiological conditions, ghrelin is secreted in a rhythmic pattern of expression with circadian light-dark cycles, and a unique secretory pattern with surges preceding meals (2).

Ghrelin secretion mechanisms occur in part by means of the GHS-R receptor, depending on growth hormone effect $(3)$, which is not completely understood yet, with potential regulation by insulin (4). Recent studies show that cultured newborn rat stomach cells can express the insulin receptor, suggesting that insulin may play an important role in this regulation. Indeed, ghrelin secretion is inhibited when the animal is exposed to low and moderate concentrations of insulin, but this inhibitory effect seems to be lost in the presence of very high concentrations of insulin (4). Moreover, in obese hyper-insulinemic patients with diabetes, fasting ghrelin is suppressed, suggesting that adiposity and insulin-resistance can interfere in ghrelin regulation (5). Thus, it is important to understand the relationship between ghrelin and insulin resistance outside the context of obesity.

Peptide YY (PYY) is a satiety peptide mainly secreted by $\mathrm{L}$ cells at the distal intestine and colon in response to food intake. It is rapidly metabolized to its active form, $\operatorname{PYY}_{(3-36)}$, by means of the action of dipeptidyl peptidase IV (DPP-IV) (6). PYY ${ }_{(3-36)}$ has been implicated as a satiety peptide inhibiting food intake in both humans (7) and rodents (8), and its fasting levels have been shown to be reduced in human obesity, suggesting that it is related to adiposity (9). The association of these peptides and insulin-resistance has not been studied outside the context of obesity and hyperglycemia.

In the present study, we evaluated fasting plasma ghrelin and PYY in relation to weight and relative insulin-resistance determined by HOMA-IR in lean nondiabetic Wistar rats.

\section{MATERIALS AND METHODS}

\section{Protocol}

In a cross-sectional study, we examined 25 male Wistar rats to determine serum PYY, insulin, ghrelin and glucose. Rats weighing 200-300 g were included in this study. The animals were kept in a $12 / 12 \mathrm{~h}$ light-dark cycle, and fed standard chow and water ad libitum. All experimental procedures were performed in accordance with the animal welfare guidelines of the institution and were approved by the Ethics Committee in Animal Research at Hospital de Clinicas de Porto Alegre, Porto Alegre, RS, Brazil.

\section{Sample collection}

After 12-hour overnight fasting, blood was collected from the retro-orbital artery in a glass cannula directly into an eppendorf tube. Simultaneously to the blood collection, Pefabloc ${ }^{\circledR}$ SC (AEBSF) $\left(\right.$ Roche $^{\circledR}$, Mannheim, Germany) was added to ghrelin at $1 \mathrm{mg} / \mathrm{mL}$ of total blood. Samples were not pre-acidified. Blood was mixed with Pefabloc ${ }^{\circledR}$ less than $30 \mathrm{~s}$ after collection. Then it was immediately placed in an ice-bath and centrifuged at $1,000 \mathrm{xg}$ for 10 minutes at room temperature, according to the manufacturer's instructions. Serum was stored at $-80^{\circ} \mathrm{C}$ until the assay was performed.

\section{Hormone and biochemistry measurements}

Total Ghrelin, $\operatorname{PYY}_{(3-36)}$, and insulin were determined by Lumine ${ }^{\circledR}$ using kits purchased from Linco Research ${ }^{\circledR}$ (Millipore $^{\circledR}$, Billerica, MA). Acylated ghrelin is the bioactive form of ghrelin; however, total ghrelin seems to be a good surrogate for the acylated form because the ratio of the two molecular forms is constant under a wide variety of conditions that affect this peptide $(5,10,11)$. Respective limits of detection for ghrelin, PYY and insulin were: 2,16 , and $28 \mathrm{pg} / \mathrm{mL}$. Capillary blood collected from the tail was used to determine blood glucose values using a glucometer (Medisense ${ }^{\circledR}$ Optium Xceed Meter).

\section{Statistical analysis}

HOMA-IR was ranked a priori to determine the median, which was the cut-off value used to categorize insulin resistance. Rats above HOMA-IR median value were considered insulin resistant (IR). Those below the median were defined as insulin sensitive (IS). Asymmetric data were log transformed and, thus, variables 
were presented as means and standard deviations. Differences between IR and IS groups were determined using the Student t-Test. For the study of correlations, we used multiple linear regression and Pearson's correlation test for all variables. SPSS version 17 was used. A $p$ value of 0.05 was considered significant.

\section{RESULTS}

According to HOMA-IR rank, we determined insulin resistant (IR group) ( $\mathrm{n}=13)$ and insulin sensitive (IS group) $(\mathrm{n}=\mathrm{12})$ rats. HOMA-IR median cut-off for insulin resistance was 2.62. Median HOMA-IR and interquartile range values for IS and IR groups were respectively: [1.56 (0.89-2.16) and $4.06(3.50-4.61)$; $p<0.001$ ] (Table 1).

We verified that the IR group presented significantly higher levels of fasting ghrelin, PYY and insulin than the IS group: [ $50.35(25.99-74.71) \mathrm{pg} / \mathrm{mL} v s .12 .33$ $(8.77-15.89) \mathrm{pg} / \mathrm{mL} ; p=0.001]$, [54.38 (37.50$71.26) \mathrm{pg} / \mathrm{mL}$ vs. $33.17(22.34-43.99) \mathrm{pg} / \mathrm{mL} ; p=$ 0.016], [18.04 (14.48-21.60) uU/mL vs. 7.09 (4.83 -9.35) uU/mL; $p=0.001$ ] (Table 1 ).

The IR and IS groups did not differ in body weight and fasting glucose values: $[292.90 \pm(10.84) \mathrm{g} v \mathrm{v}$. $289.95 \pm(10.32) \mathrm{g} ; p=0.495],[97 \pm(10.48) \mathrm{mg} / \mathrm{dL}$ vs. $91 \pm(12.45) \mathrm{mg} / \mathrm{dlL} ; p=0.201$ ] (Table 1$)$.

Fasting ghrelin, but not PYY, correlated directly with HOMA IR: $(\mathrm{r}=0.52 ; p=0.008)$ and $(\mathrm{r}=0.22 ; p=$ 0.200 ) (Figures $\mathrm{IA}$ and $\mathrm{IB}$, respectively). Fasting ghrelin was significantly correlated with body weight (Figure IC) and fasting insulin: $(\mathrm{r}=0.54 ; p=0.005)$ and $(\mathrm{r}=$ $0.51 ; p=0.009)$. Fasting PYY did not correlate with insulin: $(\mathrm{r}=0.32 ; p=0.119)$ or body weight $(\mathrm{r}=0.2$; $p=0.921)$ (Figure 1D). Fasting ghrelin and PYY peptides did not correlate with each other. $(\mathrm{r}=0.37 ; p=0.069)$.

Table 1. Sample characteristics*

\begin{tabular}{lccc}
\hline & $\begin{array}{c}\text { IS Group } \\
(\mathbf{n = 1 2})\end{array}$ & $\begin{array}{c}\text { IR Group } \\
(\mathbf{n = 1 3})\end{array}$ & $\mathbf{P}$ \\
\hline Body weight $(\mathrm{g})$ & $289.95 \pm(10.32)$ & $292.90 \pm(10.84)$ & 0.495 \\
Glucose $(\mathrm{mg} / \mathrm{dL})$ & $91 \pm(12.45)$ & $97 \pm(10.48)$ & 0.201 \\
Insulin $(\mathrm{uU} / \mathrm{mL})$ & $7.09[4.83-9.35]$ & $18.04[14.48-21.60]$ & 0.001 \\
HOMA-IR & $1.56(0.89-2.16)$ & $4.06(3.50-4.61)$ & $<0.001$ \\
Ghrelin $(\mathrm{pg} / \mathrm{mL})$ & $12.33[8.77-15.89]$ & $50.35[25.99-74.71]$ & 0.001 \\
PYY (pg/mL) & $33.17[22.34-43.99]$ & $54.38[37.50-71.26]$ & 0.016 \\
\hline
\end{tabular}

* Comparison between groups by $t$ - test for two independent samples. Body weight and glucose are expressed in mean and standard deviation. HOMA-IR values are shown in median and interquartile ranges. Other variables are expressed in mean and Confidence Interval. IS group $=$ insulin sensitive group; $\mathbb{R}$ group $=$ insulin resistant group .

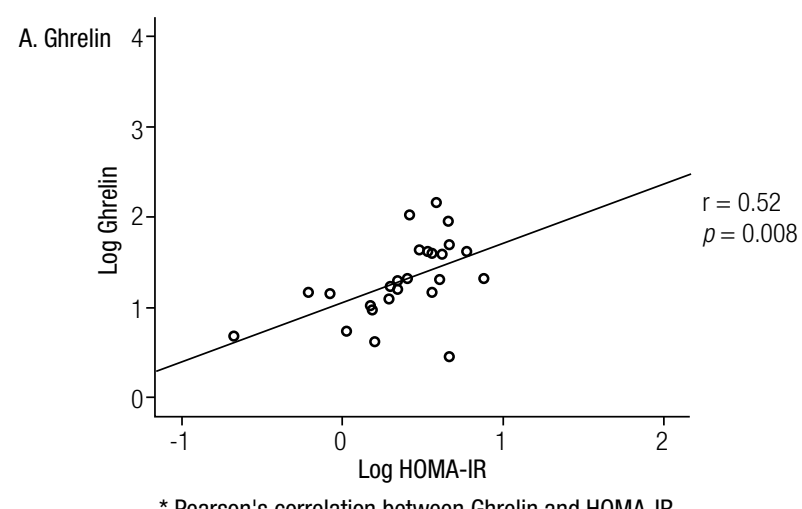

* Pearson's correlation between Ghrelin and HOMA-IR
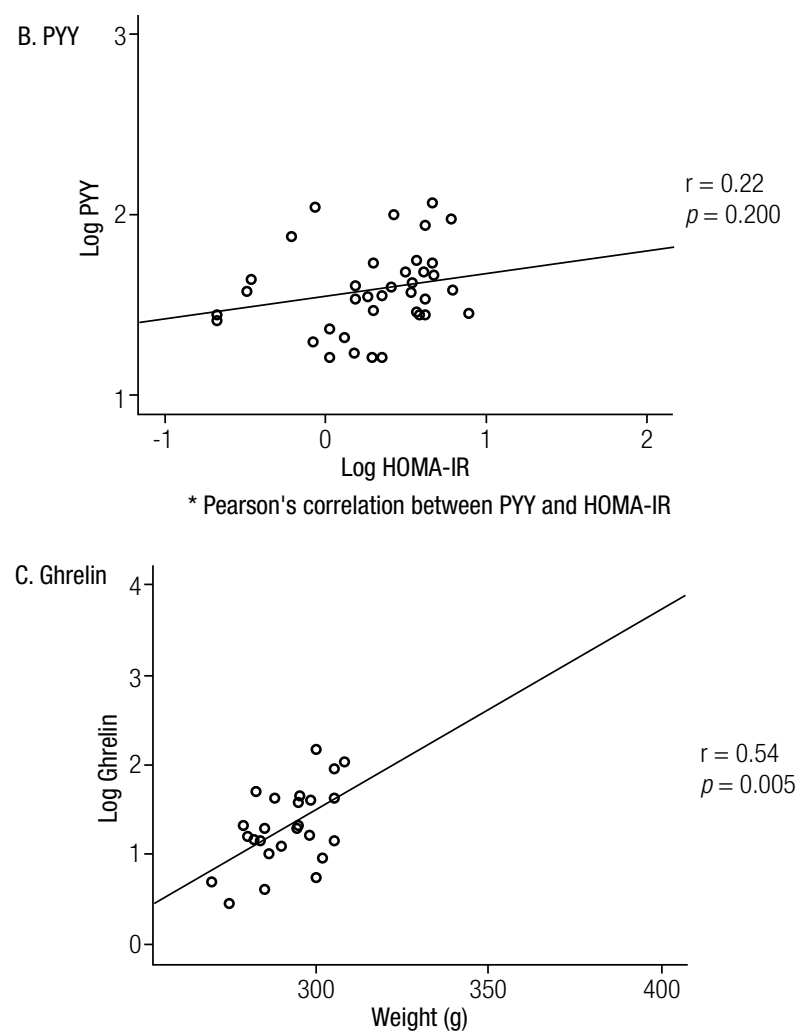

* Pearson's correlation between Ghrelin and body weight

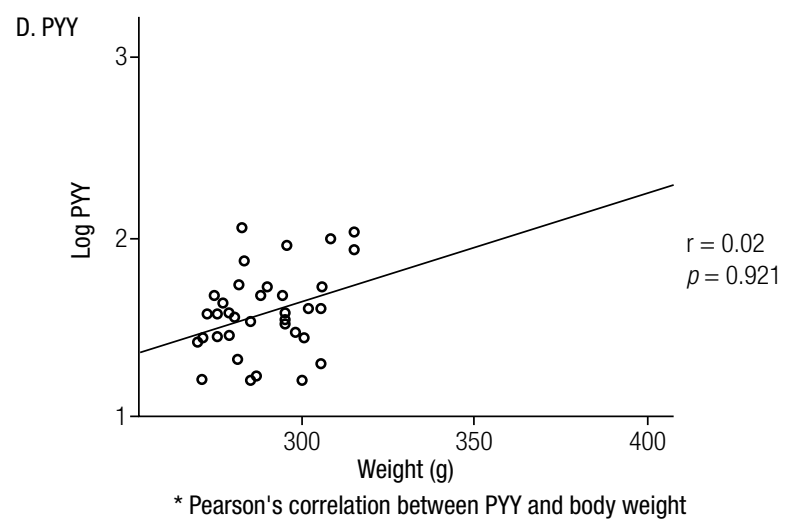

Figure 1. Pearson's correlations between Ghrelin vs. HOMA-IR (A); PYY vs. HOMA-IR (B); Ghrelin vs. Weight (C) and PYY vs. Weight. Data were log transformed for analysis. 


\section{DISCUSSION}

The present study shows that, in Wistar rats, fasting ghrelin is associated with insulin-resistance, independently of body weight. The same effect was not observed for PYY ${ }_{(3-36)}$. This finding suggests that ghrelinsecreting cells may be up-regulated in the fasting state by the presence of insulin-resistance without the interference of weight.

So far, few studies have evaluated the association between ghrelin and insulin-resistance. In newborn rat $\mathrm{X} / \mathrm{A}$ stomach cells, the secretion of ghrelin is progressively inhibited by increasing concentrations of insulin. However, this effect is abolished by higher concentrations of insulin by the inhibition of phospho-inositol-3 kinase, thus suggesting that cellular insulin resistance can impair the suppressive effect of insulin in fasting ghrelin (4). In another study, the ablation of the ghrelin receptor (growth hormone secretagogue receptor - GHS-r) in knockout Ghsr-/- mice, compared with wild type mice, improved the natural age-related insulin-resistance, reinforcing a role of ghrelin in the insulin-resistant state (12). Moreover, in healthy overweight subjects receiving ghrelin infusions over 2 hours along with endovenous insulin and somatostatin, an acute muscle insulin resistance was produced by ghrelin (13). On the other hand, when evaluating fasting ghrelin levels in cross-sectional studies with insulin-resistant hyperinsulinemic obese patients, ghrelin levels are decreased, indicating a possible suppressive effect of insulin in ghrelin secretion in the presence of obesity (5). In the present study, we observed a significant positive association between ghrelin and insulin-resistance and an independent association between ghrelin and weight, which is in accordance with the above findings and reinforce the concept that insulin resistance may up-regulate fasting ghrelin secretion in the absence of obesity.

The relationship between PYY and insulin-resistance has been controversial. In relatives of type 2 diabetic patients, fasting serum PYY has been shown to be low and to correlate negatively with insulin resistance (14). However, in a larger recent study of type 2 diabetic patients with coronary artery disease, the serum active form of $\mathrm{PYY}_{(3-36)}$ in the fasting state was positively correlated with serum insulin levels and to body mass index (9). This study also showed that abdominal adiposity was an important determinant of PYY (3-36) $_{\text {concentra- }}$ tion in type 2 diabetic subjects, and the higher $\operatorname{PYY}_{(3-36)}$ levels could be due to the higher adiposity of the pa- tients. However, the authors found that the association between high fasting $\operatorname{PYY}_{(3-36)}$ did not depend on total or regional adiposity. It was then speculated that the two forms of PYY may have different effects on insulin metabolism, with $\mathrm{PYY}_{(1-36)}$ having a more potent role in insulin secretion than $\operatorname{PYY}_{(3-36)}$, while $\operatorname{PYY}_{(3-36)}$ may have an increased impact on insulin-resistance than $\mathrm{PYY}_{(\mathrm{I}-}$ 36) Our results did not confirm an association between insulin-resistance and fasting PYY levels in the present model, suggesting that mild insulin-resistant states could be insufficient to influence the increase in fasting ghrelin and $\mathrm{PYY}_{(3-36)}$ in lean animals. We cannot exclude, however, that the response of PYY to food overload would be altered in the setting of insulin resistance.

The present study has clear limitations because of the cross-sectional design, which does not enable inferring causality between insulin-resistance and the secretion of both peptides. We believe, however, that insulin-resistance may be the most logical causative factor because of the presence of insulin receptors in stomach cells. Longitudinal studies are necessary to further clarify the natural history of insulin-resistance and the regulation of fasting ghrelin in this experimental model.

In conclusion, these results support a role of fasting ghrelin in the pathogenesis of insulin-resistance in Wistar rats, and the hypothesis of a possible gastrointestinal role of insulin-resistance. We speculate that the loss of insulin inhibitory effect may be an adaptive metabolic adjustment. Further studies are necessary to investigate whether insulin resistance may influence satiety and food intake by means of the effect on these peptides.

Contributor statements: Luciana da Conceição Antunes designed the study, wrote the protocol, reviewed studies, drafted the article, conducted part of the statistical analysis and interpreted the data. Manoela Neves da Jornada designed the study, wrote the protocol, reviewed studies and drafted the article. Kelly Carraro Foletto participated in the experimentation and conducted part of the statistical analysis. Marcello Casaccia Bertoluci participated in study design, wrote the protocol, interpreted the data, drafted the article and was responsible for the final approval of this version.

Acknowledgments: this study was supported by Fundo de Incentivo à Pesquisa - FIPE/HCPA, Porto Alegre/Brazil. The authors also thank Hospital de Clínicas de Porto Alegre, PostGraduation Research Group (GPPG), Luciano Guimaraes, Animal Experimentation Unity (UEA/HCPA), Marta Cioato and Fabiola Meyer. We are in debt to Dr. Eurico Camargo Neto for the special assistance with the PYY and Ghrelin determinations.

Disclosure: no potential conflict of interest relevant to this article was reported. 


\section{REFERENCES}

1. Kojima M, Hosoda $H$, Date $Y$, Nakazato $M$, Matsuo $H$, Kangawa K. Ghrelin is a growth-hormone-releasing acylated peptide from stomach. Nature. 1999;402(6762):656-60.

2. Cummings DE, Purnell JQ, Frayo RS, Schmidova K, Wisse BE, Weigle DS. A preprandial rise in plasma ghrelin levels suggests a role in meal initiation in humans. Diabetes. 2001;50(8):1714-9.

3. Fukumori R, Mita T, Sugino T, HasegawaY, Kojima M, Kangawa K, et al. Effects of intravenous ghrelin injection on plasma growth hormone, insulin and glucose concentrations in calves at weaning. Anim Sci J. 2013;84(4):310-5.

4. Gagnon J, Anini Y. Insulin and norepinephrine regulate ghrelin secretion from a rat primary stomach cell culture. Endocrinology. 2012;153(8):3646-56.

5. McLaughlin T, Abbasi F, Lamendola C, Frayo RS, Cummings DE. Plasma ghrelin concentrations are decreased in insulin-resistant obese adults relative to equally obese insulin-sensitive controls. J Clin Endocrinol Metab. 2004;89(4):1630-5.

6. Batterham $R L$, Bloom SR. The gut hormone peptide $Y Y$ regulates appetite. Ann NY Acad Sci. 2003;994:162-8.

7. Steinert RE, Feinle-Bisset C, Geary N, Beglinger C. Secretion of gastrointestinal hormones and eating control. J Anim Sci. 2013;91(5):1963-73.

8. Batterham RL, Cowley MA, Small CJ, Herzog H, Cohen MA, Dakin CL, et al. Gut hormone PYY(3-36) physiologically inhibits food intake. Nature. 2002;418(6898):650-4.
9. Ukkola OH, Puurunen VP, Piira OP, Niva JT, Lepojärvi ES, Tulppo $\mathrm{MP}$, et al. High serum fasting peptideYY (3-36) is associated with obesity-associated insulin resistance and type 2 diabetes. Regul Pept. 2011;170(1-3):38-42.

10. Murakami N, HayashidaT, Kuroiwa T, Nakahara K, IdaT, Mondal MS, et al. Role for central ghrelin in food intake and secretion profile of stomach ghrelin in rats. J Endocrinol. 2002; $174(2): 283-8$.

11. Ariyasu $H$, Takaya $K$, Hosoda $H$, Iwakura $H$, Ebihara $K$, Mori $K$, et al. Delayed short-term secretory regulation of ghrelin in obese animals: evidenced by a specific RIA for the active form of ghrelin. Endocrinology. 2002;143(9):3341-50.

12. Lin L, Saha PK, Ma X, Henshaw IO, Shao L, Chang BH, et al. Ablation of ghrelin receptor reduces adiposity and improves insulin sensitivity during aging by regulating fat metabolism in white and brown adipose tissues. Aging Cell. 2011;10(6):9961010.

13. Vestergaard ET, Gormsen LC, Jessen N, Lund S, Hansen TK, Moller $\mathrm{N}$, et al. Ghrelin infusion in humans induces acute insulin resistance and lipolysis independent of growth hormone signaling. Diabetes. 2008;57(12):3205-10.

14. Boey D, Heilbronn L, Sainsbury A, Laybutt R, Kriketos A, Herzog $H$, et al. Low serum PYY is linked to insulin resistance in firstdegree relatives of subjects with type 2 diabetes. Neuropeptides. 2006;40(5):317-24. 